


\section{DISCLAIMER}

This report was prepared as an account of work sponsored by an agency of the United States Government. Neither the United States Government nor any agency Thereof, nor any of their employees, makes any warranty, express or implied, or assumes any legal liability or responsibility for the accuracy, completeness, or usefulness of any information, apparatus, product, or process disclosed, or represents that its use would not infringe privately owned rights. Reference herein to any specific commercial product, process, or service by trade name, trademark, manufacturer, or otherwise does not necessarily constitute or imply its endorsement, recommendation, or favoring by the United States Government or any agency thereof. The views and opinions of authors expressed herein do not necessarily state or reflect those of the United States Government or any agency thereof. 


\section{DISCLAIMER}

Portions of this document may be illegible in electronic image products. Images are produced from the best available original document. 
Reference to a company or product name does not imply approval or recommendation of the product by Union Carbide Corporation or the U.S. Energy Research and Development Administration to the exclusion of others that may meet specifications.

Printed in the United States of America. Available from

National Technical Information Service

U.S. Department of Commerce

5285 Port Royal Road, Springfield, Virginia 22161

Price: Printed Copy \$4.00; Microfiche $\$ 2.25$

This report was prepared as an account of work sponsored by the United States Government. Neither the United States nor the Energy Research and Development Administration, nor any of their employees, nor any of their contractors, subcontractors, or their employees, makes any warranty, express or implied, or assumes any legal liability or responsibility for the accuracy, completeness or usefulness of any information, apparatus, product or process disclosed, or represents that its use would not infringe privately owned rights. 
Distribution Category: UC-25

\title{
BOND STRENGTH OF URETHANE AND EPOXY-MODIFIED ADHESIVES
}

\author{
F. G. Childress \\ A. K. Zava \\ C. E. Miller
}

Ceramics and Plastics Development Department

Y-12 Development Division

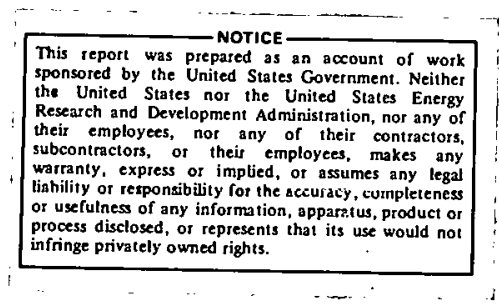

Oak Ridge Y-12 Plant

P. O. Box Y, Oak Ridge, Tennessee 37830

Prepared for the US Energy Research and Development Administration

Under US Government Contract W-7405-eng-26 


\section{ABSTRACT}

A number of urethane and epoxy-modified urethane systems were evaluated as room-temperature-curing adhesives. The systems were formulated to yield a variety of modulus levels and to be compatible with certain chemically sensitive materials. 


\section{CONTENTS}

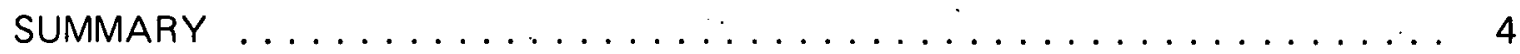

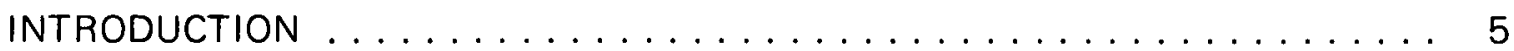

BOND STRENGTH OF ADHESIVES $\ldots \ldots \ldots \ldots \ldots \ldots \ldots \ldots$

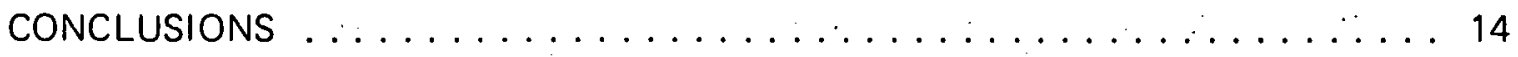

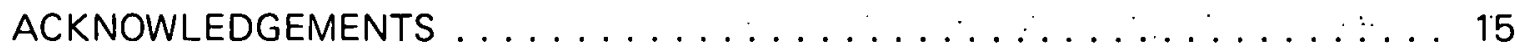




\section{SUMMARYY}

A number of urethane and epoxy-modified urethane systems were evaluated as room-temperature-curing adhesives suitable for bonding chemically sensitive materials.

Cure time was evaluated as functions of viscosity, hardness, adhesive tensile strength, and T-peel strength.

All systems except one were based on Du Pont Adiprene prepolymers (L-1,00, L-315, LW-520) cured with polyols or aromatic diamines. The Adiprenes are reaction products of polybutylene ether glycol and toluene diisocyanate ( $L-100$ and $L-31.5$ ) or dicyclohexyl methane-4,4'-diisocyanate (LW-520). One system was based on a polyol-cured polybutadiene-based elastomer.

The data provide means for adhesive selection or further modification according to use or end-product properties. 


\section{INTRODUCTION}

Adhesive bonding of a number of chemically sensitive materials has been accomplished in the recent past with urethane adhesives. Additional urethane formulations are being evaluated at the Oak Ridge Y-12 Plant (a) in order to provide a series of systems with a variety of properties.

(a) Operated by the Union Carbide Corporation's Nuclear Division for the US Energy Research and Development Administration. 


\section{BOND STRENGTH OF AD̄HESIVES}

Two series of comparative studies have evolved as a result of the need for selectivity in adhesive properties. Adhesive systems were formulated primarily from commercially recommended or available resins and curing agents to provide products of varying moduli. The first series of tests involved adhesive T-peel evaluation (with aluminum) as a function of the cure time with nine formulations. The second series of eight formulations included T-peel evaluation with aluminum and carbon steel and tensile with aluminum. Four adhesives of the first series were further evaluated in the second series, making a total of 13 systems under consideration. These systems are listed in Table 1 and further identified in Table 2. The room-temperature modulus order for fully cured systems is shown in Table 3. This information should be used with caution due to variation in rate sensitivity of the various systems.

Tablo 1

ADHESIVE SYSTEMS

\begin{tabular}{cll}
\hline $\begin{array}{c}\text { Adhesive } \\
\text { System }\end{array}$ & \multicolumn{1}{c}{ Components } & Weight Ratiós \\
\hline & & \\
A & L-100/MOCA & $100 / 13$ \\
B & L-100/Polyol/FAA & $100 / 4.3 / 0.01$ \\
C & L-315/Polyol/FAA & $100 / 9.2 / 0.03$ \\
D & L-315/Polyol/FAA & $100 / 10 / 0.03$ \\
E & LW-520/Eutectic & $100 / 7.5$ \\
F & LW-520/BDO/FAA & $100 / 6.1 / 0.005$ \\
G & EN-7(A)/EN-7(B) & $100 / 17.5$ \\
H & LW-520/ER-508/Eutectic & $60 / 40 / 12$ \\
J & LW-520/ER-508/Eutectic & $40 / 60 / 14$ \\
M & L-315/Polyol/Dabon & $100 / 9.2 / 0.02$ \\
N & LW-520/ER-508/Eutectic & $100 / 20 / 11$ \\
P & LW-520/ER-508/Eutectic & $50 / 50 / 13$ \\
R & L-100/Polyol/Dabco & $100 / 4.3 / 0.01$ \\
\hline
\end{tabular}

Cure rate as a function of viscosity was dotormined tor all the sy/stems in thit SH: : IIIII series and two from the first series. System $D$ was not tested since it was not significantly different from System C. Systems $H$ and $J$ were not significantly different from System $P$ and, likewise, were not tested.

Typical viscosity curves are presented in Figure 1. Both formulations of polyol-cured Adiprene L-100 (Systems B and R) exhibited the slowest cure rates. There was no significant difference in the catalytic effect of ferricacetylacetonato (FAA) and 1.4-diazabicyclo (2.2.2) octane (Dabco)

Table 2

COMPONENT IDEPSTIFICATION FOR ADHESIVE SYSTEMS

\begin{tabular}{ll}
\hline \multicolumn{1}{c}{ Components } & \multicolumn{1}{c}{ Idenlification } \\
\hline L-100, L-315, LW-520(1) & Adiprene (Dupont) \\
MOCA & 4,4'-Methylene-bis-2-chloroaniline (Dupont) \\
Polyol (7/2 ratio) & 1,4-Butanediol (BDO)/trimethylolpropane (TMP) \\
FAA & Ferricar.erylar.etnnntc \\
Eutectic (40/60 ratio) & Methylenedianiline (MDA)/metaphenylenediamine (MPDA) \\
8DO & 1,4-Butanediol \\
EN-7(A) (2) & Conathane (Conap, Inc) \\
EN-7(B) & FAA-catalyzed blend of polyols \\
ER-508 (3) & Epi-Rez epoxy (Celanese) \\
Dabco & 1,4-Didzabicyclo [2.2.2] octonc (Houdry) \\
\hline
\end{tabular}

(1) L-100 and L-315-Reaction products of polybutylene ether glycol and toluene diisocyanate. LW-520-Reaction product of polybutylene ether glycol and dicyclohexyl methane-4,4'diisocyanate.

(2) EN-7-Polybutadiene-based elastomer.

(3) ER-508-High-purity diglycidyl ether of Bisphenol A. 
Table 3

MODULUS RATING ORDER

\begin{tabular}{lll}
\hline Adhesive & \multicolumn{1}{c}{ Type } & Modulus \\
\hline $\mathrm{J}$ & Urethane-epóxy & Highest \\
$\mathrm{P}$ & Urethane-epoxy & \\
$\mathrm{H}$ & Urethane-epoxy & \\
$\mathrm{N}$ & Urethane-epoxy & \\
$\mathrm{A}, \mathrm{E}$ & Amine-cured urethane \\
$\mathrm{C}, \mathrm{D}, \mathrm{M}$ & Urethane-polyols(1) \\
$\mathrm{F}$ & Urethane-diol & \\
$\mathrm{G}, \mathrm{R}, \mathrm{B}$ & Urethane-polyols & Lowest \\
\hline (1) These systems exhibit high creep with the modulus \\
\multicolumn{3}{c}{ being highly rate sensitive. }
\end{tabular}

with this prepolymer. In contrast, the L-315 prepolymer cures much more rapidly with the Dabco catályst (System M) than with the FAA catalyst (System C). These systems were recommended by $\mathrm{H}$. $\mathrm{G}$. Hammon of the Lawrence Livermore Laboratory. Systems containing LW-520 exhibited the highest initial viscosities, with the eutectic amine-cured formulation (System E) being the most viscous.

Cure rate as a function of Shore $A$ hardness was determined for nine of the adhesives.

Systems $B, D, H$, and $J$ were not tested since they were not significantly different from the other systems. Typical hardness curves (Figure 2) are shown for the immediate reading and for that observed after a one-minute indentation. System M (L-325/polyol/Dabco) appears, from these data, to attain a useable hardness level at the earliest cure time. System $F$ ( $L W-520 / B D O / F A A)$, though not tested at an eight-hour cure level, may be as rapid in cure. Its creep resistance, as determined by the one-minute indentation readings, is acquired at the earliest cure time.

The first series of bond-strength tests were performed with T-peel specimens per a modified procedure of ASTM D-1876. A constant head speed of $50 \mathrm{~mm} / \mathrm{min}$ was used rather than the prescribed $250 \mathrm{~mm} / \mathrm{min}$. Bonding, aging, and testing were performed at $20^{\circ} \mathrm{C}$ in a controlled-humidity environment $(10 \% \mathrm{rh})$. Specimens were fabricated from $600-\mu \mathrm{m}$-thick aluminum sheet (AA-1100- -144$)$ and were sheared to width $(25 \mathrm{~mm})$ after bonding. Bondline thicknesses of approximately $380 \mu \mathrm{m}$ were employed. Aluminum was prepared for bonding by etching in a solution of sodium dichromate and sulfuric acid.

Specimens were tested at cure-time intervals of $4,7,14,30,60,120$, and 240 days at a $20^{\circ} \mathrm{C}$ aging temperature. Two specimons of each adhesive were postcured for 3 hours at $90^{\circ} \mathrm{C}$ after curing 7 days at $20^{\circ} \mathrm{C}$. These specimens were not aged. The results of these tests are shown, graphically, in Figure 3. Maximum strength over the time period involved was attained with Systems C and D. There was no significant difference in these systems. Though strengths of approximately $90 \mathrm{~N} / \mathrm{cm}$ width were noted after a 7-day rure, final stieriyllı dippears to have stabilized at approximately $60 \mathrm{~N} / \mathrm{cm}$ width. This value is better than twice the strength of the next best system, System $\mathrm{G}$.

Correlation of hardness and peel-strength data indicates a possible relationship between strength and creep, with creep being determined by observing the difference in hardnesses from the immediate to one-minute indentation readings. System $\mathrm{C}$ demonstrates the most creep per this test. Another correlation appears to be that maximum peel strength is attained well before maximum hardness is reached.

Strengths of postcured specimens were greater than respective stabilized strengths (8-month cure). Pestcured specimens were not aged, however. On the average, these strengths are not significantly different from the 7-day-cured groups, which represent similar aging (see Table 4). 


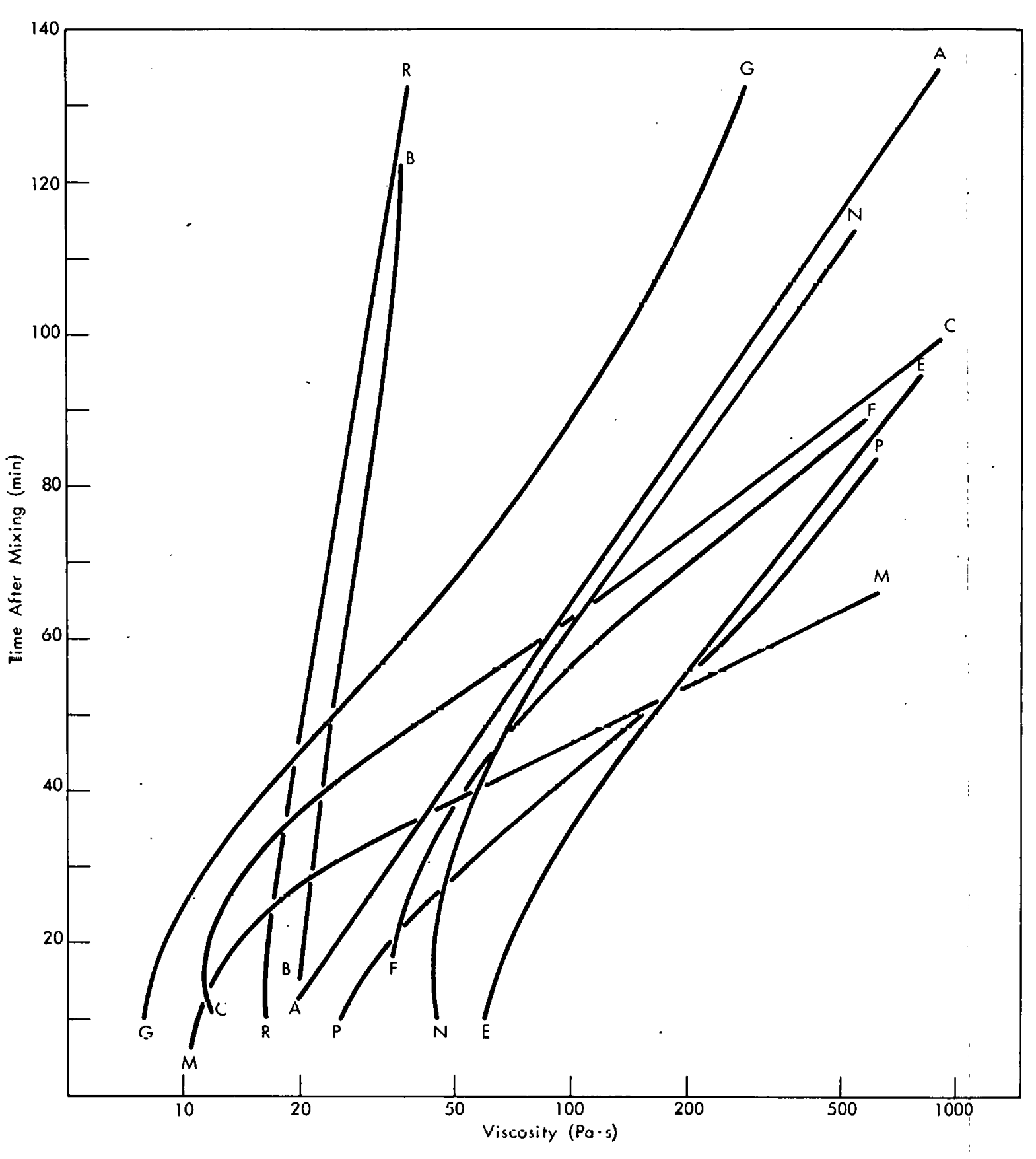

Figure 1. TYPICAL VISCositY CURVEs.ISee Table 1 for Adhesive törmulations)
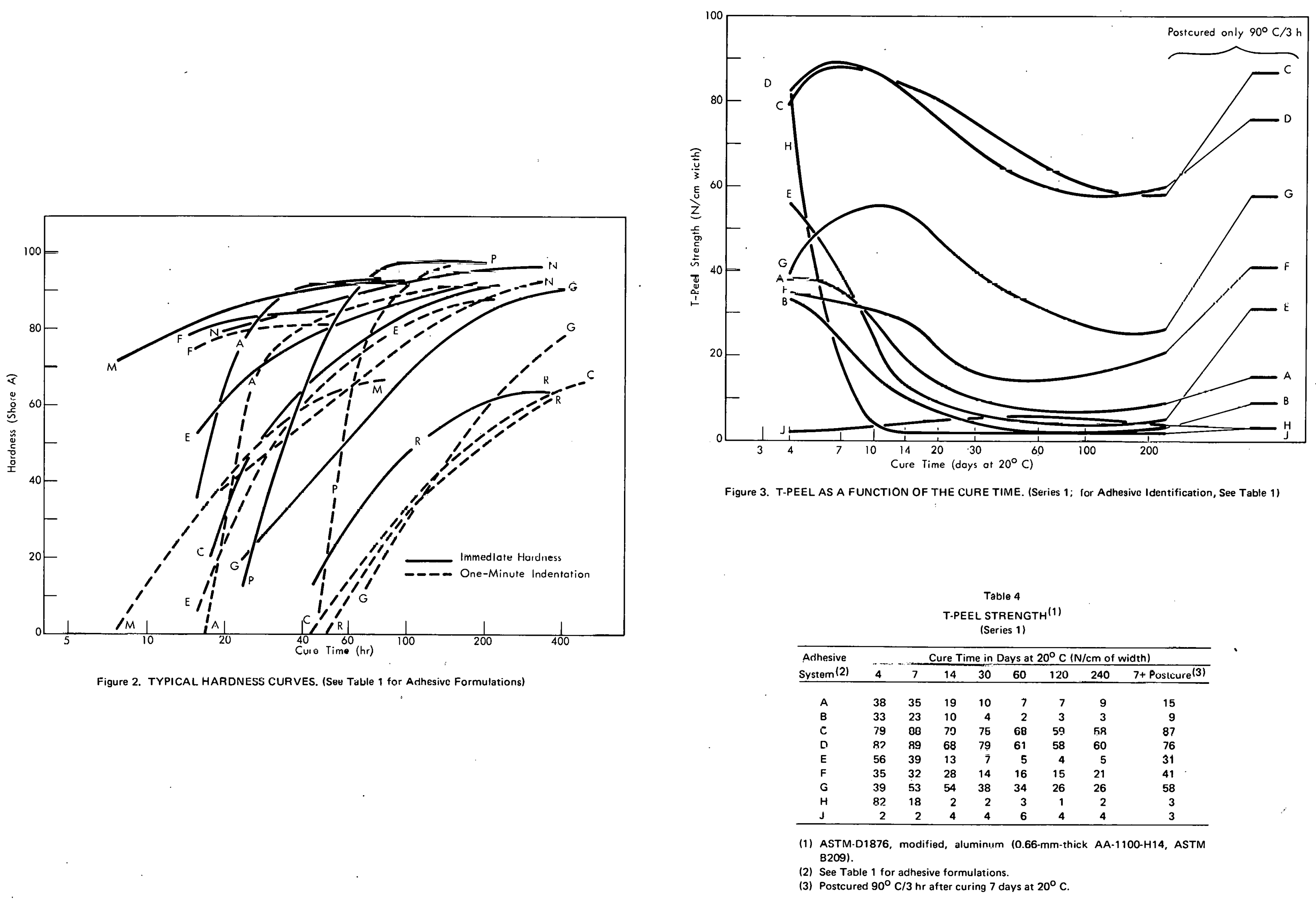
Additional tests were initiated to determine whether strength reduction with time was a function of bond deterioration, or a change in physical properties (modulus or creep). Peel strengths with carbon steel and aluminum (Table 5) and tensile strengths with aluminum (Table 6) are reported graphically in Figures 4 through 11. Tensile strengths tended to increase in strength through the first 60 days of cure and experienced little change

Table 5

T-PEEL STRENGTH(1)

(Series 2)

\begin{tabular}{|c|c|c|c|c|c|c|c|c|}
\hline \multirow{2}{*}{$\begin{array}{l}\text { Adhesive } \\
\text { System (2) }\end{array}$} & \multirow{2}{*}{$\begin{array}{l}\text { Specimen } \\
\text { Type (3) }\end{array}$} & \multicolumn{7}{|c|}{ Cure of Age $(4)$ Time in Days at $20^{\circ} \mathrm{C}(\mathrm{N} / \mathrm{cm}$ of width $)$} \\
\hline & & 3 & 7 & 14 & 30 & 60 & 140 & 240 \\
\hline \multirow[t]{2}{*}{ c } & Al & 89 . & $72(93)$ & 74 & $74(105)$ & $79(88)$ & $74(103)$ & $60(77)$ \\
\hline & $\mathrm{Fe}$ & 60 & $63(102)$ & 72 & $84(105)$ & $79(86)$ & $79(91)$ & $68(86)$ \\
\hline \multirow[t]{2}{*}{ E } & $\mathrm{Al}$ & 51 & $38(52)$ & 33 & $21(61)$ & $12(60)$ & $5(58)$ & $5(56)$ \\
\hline & $\mathrm{Fe}$ & 65 & $58(102)$ & 47 & $35(74)$ & $44(88)$ & $30(70)$ & $37(77)$ \\
\hline \multirow[t]{2}{*}{$\mathrm{F}$} & Al & 56 & $63(94)$ & 61 & $51(86)$ & $49(77)$ & $44(65)$ & $32(40)$ \\
\hline & $\mathrm{Fe}$ & - 30 & $32(60)$ & 24 & $28(60)$ & $24(30)$ & $30(40)$ & $21(38)$ \\
\hline \multirow[t]{2}{*}{$G$} & Al & 51 & $54(68)$ & 52 & $46(66)$ & $47(63)$ & $42(60)$ & $40(66)$ \\
\hline & $\mathrm{Fe}$ & 49 & $56(94)$ & 66 & $93(89)$ & $52(84)$ & $51(79)$ & $52(77)$ \\
\hline \multirow[t]{2}{*}{ M } & Al & 84 & $82(102)$ & 72 & $79(91)$ & $72(105)$ & $58(91)$ & $58(74)$ \\
\hline & $\mathrm{Fe}$ & 91 & $80(116)$ & 93 & $108(117)$ & $79(107)$ & $98(108)$ & $68(89)$ \\
\hline \multirow[t]{2}{*}{$N$} & Al & 70 & $54(32)$ & 42 & $28(40)$ & $21(37)$ & $18(28)$ & $12(30)$ \\
\hline & $\mathrm{Fe}$ & 79 & $80(56)$ & 63 & $66(66)$ & $46(49)$ & $37(54)$ & $47(52)$ \\
\hline \multirow[t]{2}{*}{$\mathbf{P}$} & Al & 4 & $5(7)$ & 7 & $5(7)$ & $2(5)$ & $4(7)$ & $4(5)$ \\
\hline & $\mathrm{Fe}$ & 14 & $14(37)$ & 5 & $7(26)$ & $7(28)$ & $4(28)$ & $4(19)$ \\
\hline \multirow[t]{2}{*}{$R$} & Al & 46 & $40(49)$ & 21 & $16(37)$ & $12(26)$ & $5(19)$ & $4(18)$ \\
\hline & $\mathrm{Fe}$ & 46 & $42(38)$ & 37 & $35(32)$ & $19(21)$ & $4(14)$ & $4(12)$ \\
\hline
\end{tabular}

(1) ASTM-D1876, modified.

(2) See Table 1 for adhesive formulations.

(3) Al - 0.6-mm-thick AA-1100-H14, ASTM B209.

Fe - 0.45-mm-thick cold finished carbon steel, ASTM A366.

(4) Strengths shown in parentheses are of specimens cured at $20^{\circ} \mathrm{C}$ for 3 to 7 days, postcured 4 hrs at $90^{\circ} \mathrm{C}$. Time is sum of $20^{\circ} \mathrm{C}$ cure and post aging times.

Table 6

ADHESIVE TENSILE STRENGTHS (1)

(All Values in MPa)

\begin{tabular}{|c|c|c|c|c|c|c|c|c|}
\hline \multirow{2}{*}{$\begin{array}{l}\text { Adhesive } \\
\text { System (2) }\end{array}$} & \multicolumn{7}{|c|}{$\begin{array}{c}\text { Cure Time } \\
\text { (days at } 20^{\circ} \mathrm{C} \text { ) }\end{array}$} & \multirow{2}{*}{$\begin{array}{c}\text { Postcured } \\
\left(90^{\circ} \mathrm{C}-4 \mathrm{hrs}\right)\end{array}$} \\
\hline & 3 & 7 & 14 & 30 & 60 & 128 & 240 & \\
\hline$c(3)$ & $6.1^{(4)}$ & 8.8 & 12.1 & 13.4 & 17.3 & 17.1 & 18.4 & - \\
\hline$E(3)$ & $7.2^{(4)}$ & 13.2 & 15.3 & 16.6 & 17.0 & 12.9 & 13.4 & - \\
\hline$F$ & $9.3^{(4)}$ & 10.1 & 12.2 & 11.9 & 10.5 & 10.7 & 12.3 & 8.3 \\
\hline G & 1.7 & 3.7 & 6.9 & 8.5 & 9.9 & 1.1 .4 & 11.3 & 6.5 \\
\hline$M$ & 8.5 & 11.1 & 15.1 & 11.7 & 12.1 & 13.2 & 10.7 & 12.4 \\
\hline N & 5.2 & 10.4 & 16.0 & 15.1 & 19.9 & 23.1 & 21.2 & 23.6 \\
\hline$P$ & 10.8 & 19.6 & 19.8 & 17.0 & 20.5 & 20.4 & 21.6 & 27.7 \\
\hline$R$ & 0.5 & 1.8 & 3.2 & 2.9 & 3.0 & 2.9 & 2.9 & 1.8 \\
\hline
\end{tabular}

(1) Aluminum to aluminum (2024-T3), average of 3 specimens each.

(2) See Table 1 for adhesive formulations.

(3) Included for comparison trom previous data, approximate cure times.

(4) Four-day cure at $20^{\circ} \mathrm{C}$. 

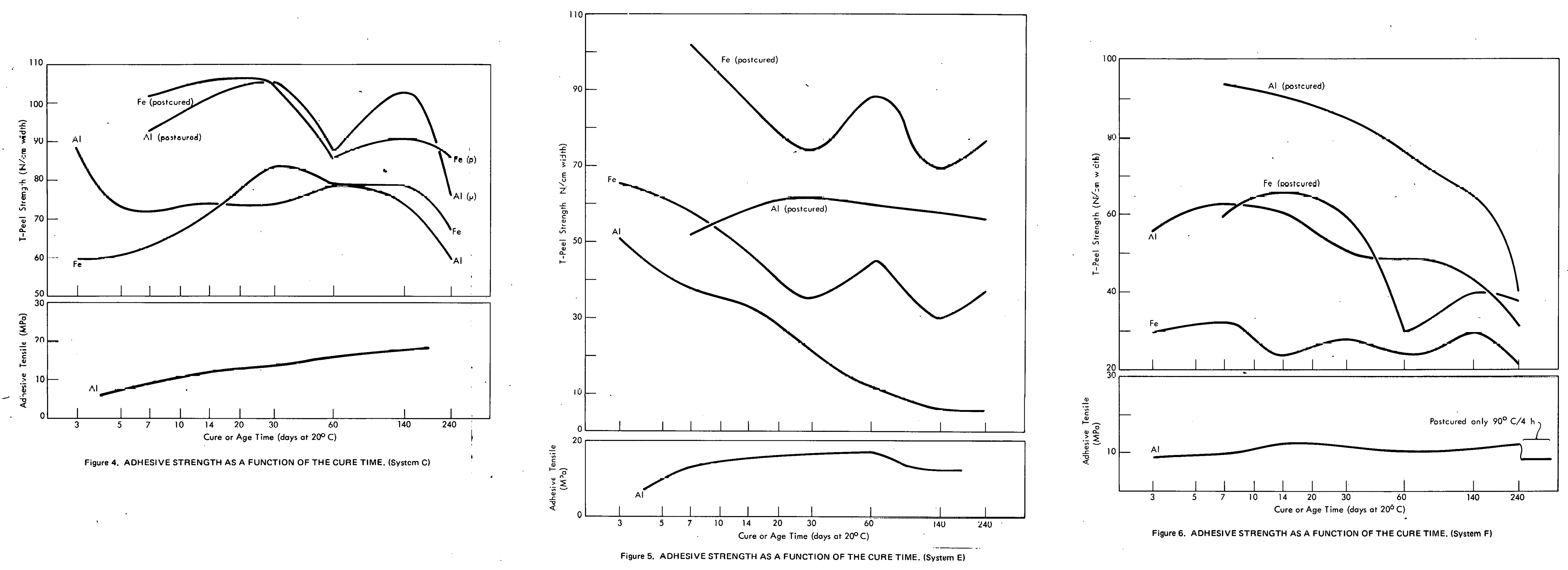

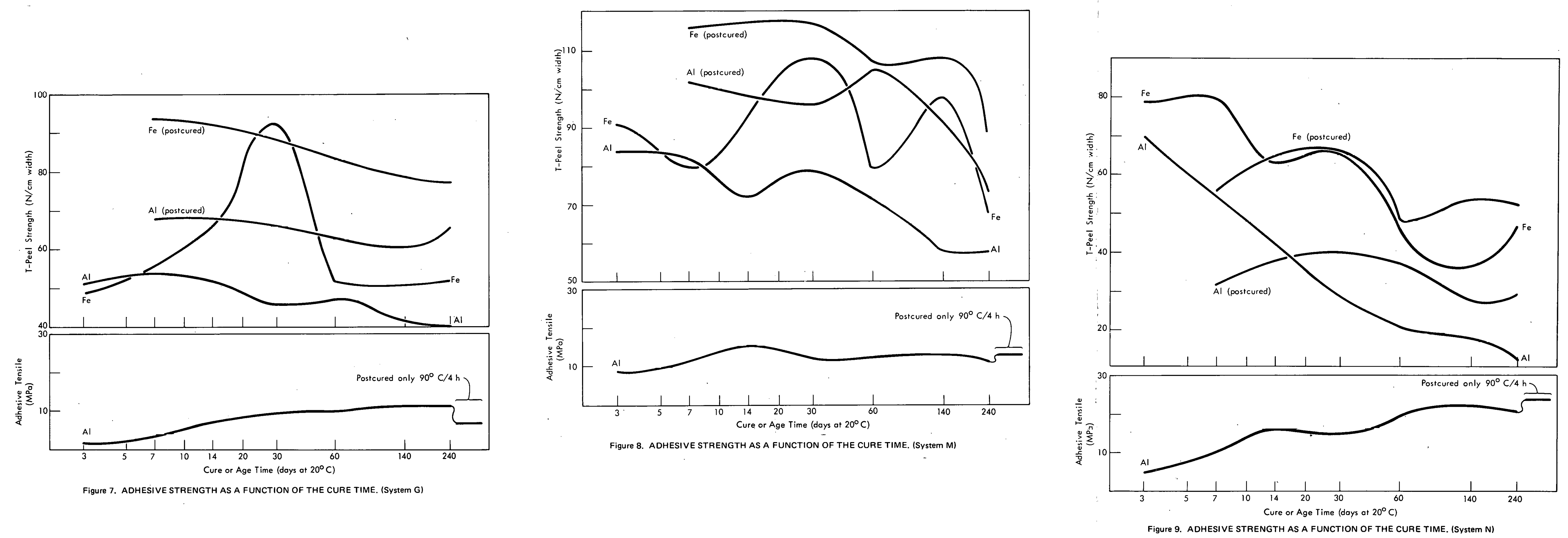

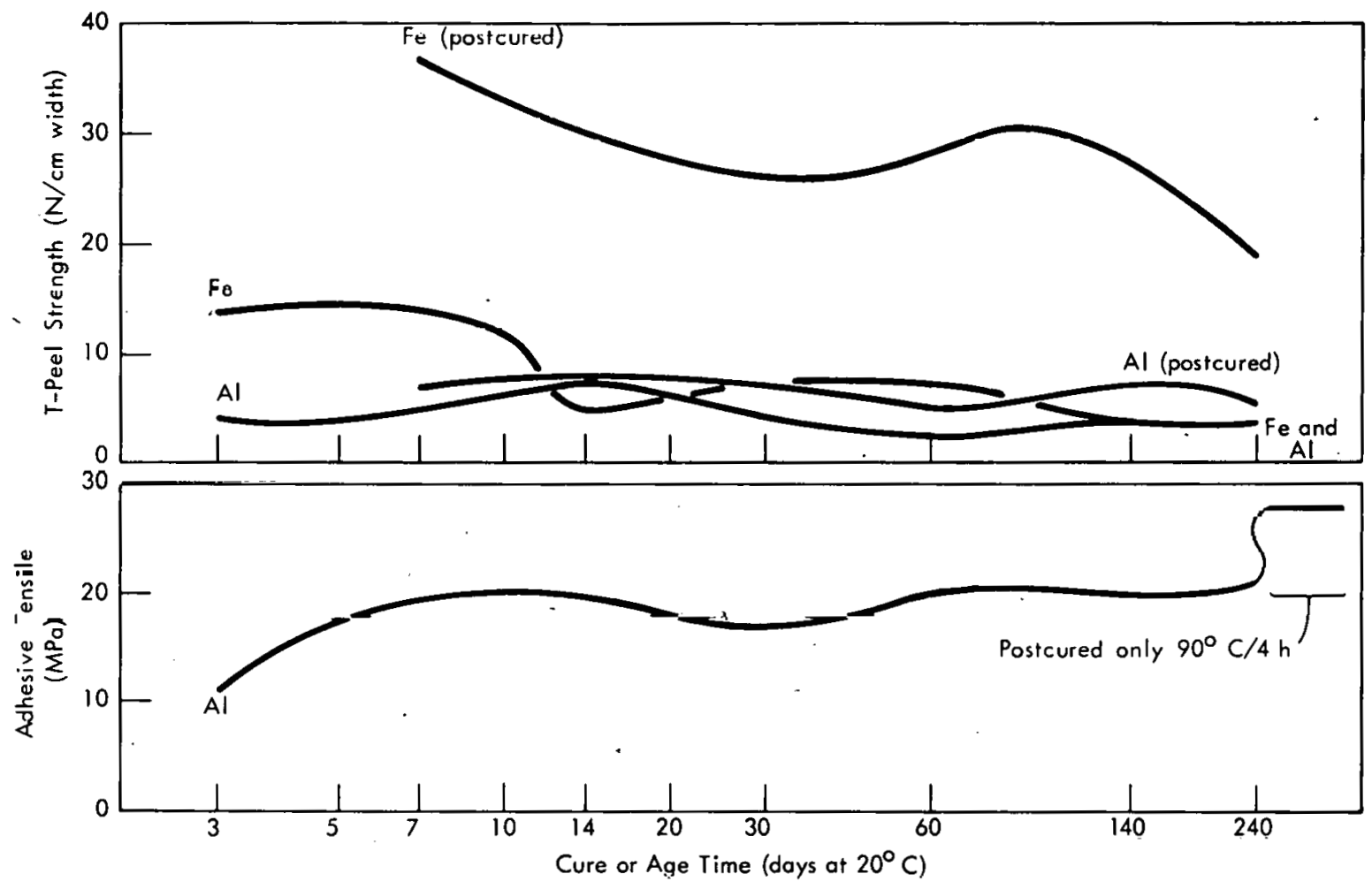

Figure 10. ADHESIVE STRENGTH AS A FUNCTION OF THE CURE 'TIME. (System P)
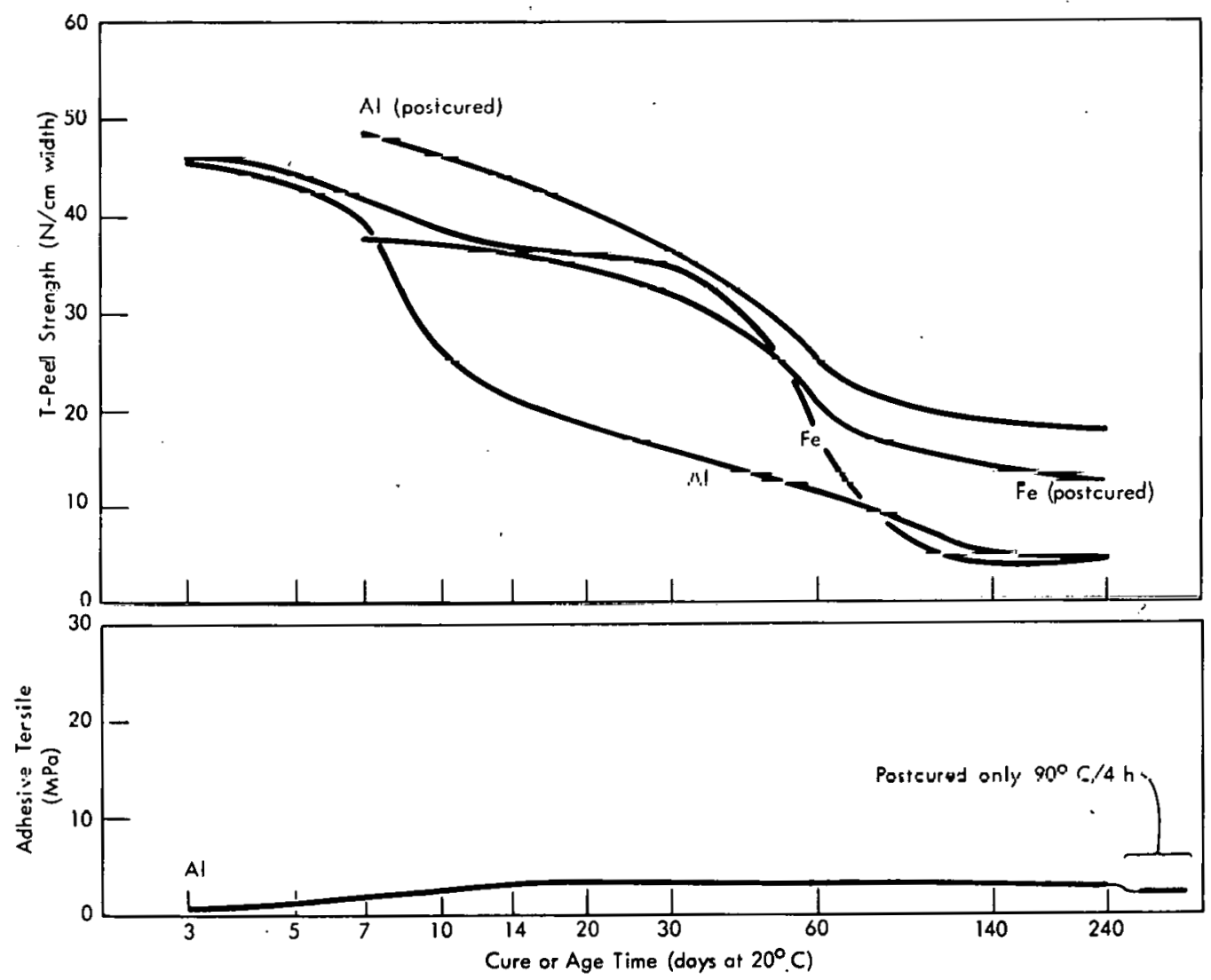

Figure 11. ADHESIVE STRENGTH AS A FUNCTION OF THE CURE TIME. (SYstem R) 
thereafter. Systems $C$ and $N$ increased slightly, while System $E$ declined. Maximum tensile strength with cure at $20^{\circ} \mathrm{C}$ was achieved with System N (23.1 MPa). System $P$ had the highest strength of all systems when postcured for 4 hours at $90^{\circ} \mathrm{C}(27.7 \mathrm{MPa})$. In contrast, this system had the lowest peel strength in each aging group.

Maximum peel strengths of the Series 2 specimens were achieved with System M-Dabco-catalyzed, polyol-cured L-315 (Figure 8). There is probably no significant difference, however, in these results and those shown for System C (Figure 4)-the FAA-catalyzed formulation. Bondlines of the Series 2 peel specimens were approximately $250 \mu \mathrm{m}$ thick. 


\section{CONCLUSIONS}

Postcured and aged peel specimens yielded higher strengths in almost all cases than respective specimens aged at $20^{\circ} \mathrm{C}$. In seven of the eight systems, tested in Series 2, peel strengths were greater with the sand-blasted steel than with the etched aluminum. An exception was noted with System F (Figure 6) which had a significantly greater strength with aluminum.

Degradation of peel strength with time appears generally less severe in the Series 2 study than in the prior tests. It is still quite pronounced, however, with Systems $E, N$, and. R, especially with aluminum specimens.

Comparative T-peel tests were made with two commercial adhesives using the same test procedures. A nitrlle epoxy, (b) structural adhesive yielded an average strength of $72 \mathrm{~N} / \mathrm{cm}$ width; whereas, an epoxy (c) adhesive averaged only $4 \mathrm{~N} / \mathrm{cm}$ width.

Under the noted conditions of bonding, aging, and testing $\left(20^{\circ} \mathrm{C}\right.$ at $\left.10 \% \mathrm{rh}\right)$, bond deterioration with either aluminum or steel is not believed to be significant. Changes in strength with time are more likely the result of changes in the physical properties of the adhesive (modulus and creep). These conclusions seem reasonable in view of the fact that most of the systems, when postcured, exhibited no significant change in strength with time. There were anomalies, however, such as those exhibited by Systems F (Figure 6) and R (Figure 11). Tensile-strength results tend to further reinforce these conclusions.

Within limits, peel strength and tendency to creep under load appcar to be directly proportinnal. The highest peel strengths were observed with those systcms with the greatest creep.

(b) Cyanamid-FM-123-2 film adhesive.

(c) Woodhill Chemical Sales-E-Pox-E. 


\section{ACKNOWLEDGEMENTS}

The authors are indebted to M. W. Poore and C. R. Settles of the Y-12 Physical Testing Department for their extensive test evaluations, and to W. E. Lever of $Y-12$ Statistical Services for the statistical evaluation. 


\section{Distribution}

Energy Research and Development Administration - Oak Ridge

Hickman, H. D.

Leed, R. E.

Lachry, D. S., Jr

Bendix - Kansas City

Jackson, $L$.

McKay, D. P.

Smith, C. H., Jr

General Electric - St. Petersburg

Creed, K.

\section{Lawrence Livermore Laboratory}

Broadman, G. A.

Firstenburg, G. S.

Garner, B. L.

Hammon, H. G.

Inouye, W. S.

Lokke, W. A./Crowley, W. B.

Moon, D. W.

Naillon, $P$.

Nelson, W. E.

Reynolds, H. L./Hatfield, R. F.

Rizzo, H. F.

Root, G. S.

Seaton, D.

Wraith, C. L.

Los Alamos Scientific Laboratory

Baker, F. B.

Burns, J. J.

Casados, E.

Deinken, H. P.

Eaton, E.

Finley, J. B.

Hoyt, H. C.

May, W. A.

Mason and Hanger - Amarillo

Laseter, W. A.

Lichte, H.W.
Monsanto Research. - Dayton

Botham, R. B.

\section{Mound Laboratory}

Hartzel, L. W./Dichiaro, J. V.

Oak Ridge Gaseous Diffusion Plant

Patton, F. S.

Stief, S. S.

Wilcox. W. J., Jr

nak Ridge National Laboratory

Pustrma, $\mathrm{H}$.

Weir, J. R., Jr

\section{Oak Ridge Y-12 Plant}

Alvey, H. E.

Armstrong, R. C.

Bagwell, B. L.

Briscoe, O.W.

Burditt, R: B.

Burkhart, L. E.

Butturini, W. G.

Childress, F. G. (5)

Day, J. R.

DeMarotta, L. J.

Dodson, W. H.

Dorsey, G. F.

Duggan, H. G.

tbert, J. W.

Ebert, T. H.

Fortenbery, M. J.

Fraser, R. J.

Gregory, J. F.

Gritzner, V. B.

Haeusler, K. R.

Jackson, V. C.

Johnson, C. E.

Jones, F. W.

Jordan, R. G.

Kahl, K. G.

Keith, A. (2)

Kite, H. T. (10)

Lever, W. E. 
Marrow, G. B.

Màrtin, J. A.

McLaughlin, L. M.

McLendon, J. D.

Miller, C. E.

Mills, J. M., Jr

Montgomery, C. D.

Morehead, J. F.

Phillips, L. R.

Poore, M.W.

Preuss, H. M.

Schreyer, J. M.

Settles, C. R.

Smith, H. F., Jr

Smith, H. M.

Smith, J. G.

Smith, R. D.

Smith, W. E.

Stoner, H. H.

Stumpfl, E.

Tewes, W. E.

Thompson, W. H., Jr

Valentine, C. K.

Waldrop, F. B.

Wayland, H. P.

Weathersby, W. E.

Whitehead, H. D.

Whitson, W. K.

Williams, R. D.

Wilson, A. H.

Yaggi, W. J./Googin, J. M.

$Y-12$ Central Files (5)

$Y$-12 Central Files (master copy)

Y-12 Central Files (route copy)

$Y-12$ Central Files ( $Y-12 R C$ )

Zava, A. K.

Zerby, C. D.

\section{Paducah Gaseous Diffusion Plant}

Levin, R. W.

\section{Sandia - Albuquerque}

DeLollis, N. J.

Quant, A.

Sandia - Livermore

Frost, R. C.

Gott, R. E.

Scholer, G. L.

Union Carbide Corporation-Parma Research Center

Chambers, W. E.

University of Tennessee-College of Engineering

Stansbury, E. E.

In addition, this report is distributed in accordance with the category UC-25, Materials, as given in the USERDA Standard Distribution Lists for Unclassified Scientific and Technical Reports, TID-4500. 